\title{
Action of fats and linoleic acid on intestinal synthesis of thiamine in thiamine-deficient rats
}

\author{
By S. K. MEGHAL AND M. C. NATH \\ University Department of Biochemistry, Nagpur, India \\ (Received 25 August 1964-Accepted 27 Fanuary 1965)
}

Evans \& Lepkovsky (1928) first reported that fat in the diet lowered the dietary requirement for thiamine. Since then several investigations have been carried out, and support for these findings has been supplied by various workers (e.g. Evans \& Lepkovsky, 1929, 1935; Whipple \& Church, 1935).

Evans, Lepkovsky \& Murphy (1934a) studied the effectiveness of different natural food fats in sparing thiamine. According to them the difference observed between hydrogenated cottonseed oil and sesame oil indicated the possibility that the chemical nature of the fat influences its sparing action upon thiamine. Later on Banerjee (1940) showed that ingestion of a high-fat diet by rats deprived of thiamine diminished the excretion of bisulphite-binding substances in urine and alleviated the severity of bradycardia.

Kemmerer \& Steenbock (1933) could not get the same results as Lepkovsky and coworkers, but they observed that, when a diet low in B vitamins and high in fat was given to rats, the tissue content of $B$ vitamins was not higher than when a diet low in $B$ vitamins and low in fat was given, thus showing that the sparing action of fat on $B$ vitamins was not due to increased conservation by the tissues. Recently, Balkrishnan \& Rajagopalan (1954) have reported from preliminary work that butterfat spares thiamine through increasing intestinal synthesis.

Our work was, therefore, undertaken to study the effect of essential fatty acids ard different food fats on urinary and faecal excretion of thiamine, the intestinal flora and tissue thiamine content.

\section{EXPERIMENTAL}

Sixty-four male albino rats were used in this study and placed individually in wirebottomed cages. No steps were taken to prevent coprophagy during the experiment. The animals were given the thiamine-free diet for a preliminary period of 5 days and, after a 5 -day depletion period, equal groups of eight animals were subjected to the regimes set out below.
(A) $15 \%$ hydrogenated groundnut oil (low-fat diet),
(B) $13 \%$ hydrogenated groundnut oil $+2 \%$ linoleic acid,
(C) $75 \%$ hydrogenated groundnut oil (high-fat diet),
(D) $70 \%$ hydrogenated groundnut oil $+5 \%$ linoleic acid,
(E) $75 \%$ groundnut oil,
(G) $75 \%$ sesame oil,
(F) $75 \%$ coconut oil,
(H) $75 \%$ butterfat. 
The compositions of the thiamine-free low-fat and high-fat diets are given in Table $\mathrm{I}$. The animals received the diets $a d$ lib. The mean final weights of the different experimental groups were the same.

The animals were given the diets for 3 months. At intervals of 15 days, the urine and faeces were collected. Urinary thiamine was determined by the thiochrome procedure, as modified by Mawson \& Thompson (1948), and thiamine in faeces as described by the Association of Vitamin Chemists (I95I). The weights of the animals were recorded weekly during the experiment.

\section{Table I. Percentage compositon of the low-fat and high-fat thiamine-free diets given to the rats}

$\quad$ Ingredient
Sucrose
Vitamin-low casein*
Fat $\dagger$
Salt mixture $\ddagger$
Vitamins

$\begin{array}{cc}\text { Low-fat diet } & \text { High-fat diet } \\ 60 & - \\ 20 & 20 \\ \text { I } 5 & 75 \\ 5 & 5 \\ - & -\end{array}$

* Acid-alcohol extracted commercial casein.

$\uparrow$ Different fats used are indicated in the text.

$\ddagger$ Jones \& Foster (1942).

$\S$ The vitamins added were $(\mathrm{mg} / \mathrm{kg}$ diet): riboflavine 7 , pyridoxine hydrochloride 5 , calcium pantothenate 25, choline chloride 1000 , nicotinic acid 25, biotin $0.75, p$-aminobenzoic acid 500 , cyanocobalamin 0.03 , vitamin $\mathrm{A}_{3}$, vitamin $\mathrm{D}_{0.4}$, vitamin $\mathrm{K} 2.5, \alpha$-tocopheryl acetate 0.5 .

The faeces were collected from four rats of each group every hour and kept in the refrigerator. The colonies of faecal coliform organisms and lactobacilli were counted by the plate method at intervals of 30 days (Balkrishnan \& Rajagopalan, 1952).

At the end of 90 days all the animals were killed by a sharp blow on the head. The thiamine contents of liver, heart and muscle were determined by the method of Kratzing \& Slater (1950). The caecal contents were weighed and digested in a flask with sufficient $0.1 \mathrm{~N}-\mathrm{HCl}$; samples were then prepared in the manner recommended, and total thiamine was determined by the method of Hennessey \& Cerecedo (1939).

\section{RESULTS}

The figures in Table 2 show that urinary and faecal excretions of thiamine, determined at intervals of 15 days, were raised in groups $D$ (hydrogenated groundnut oil + linoleic acid), E (groundnut oil), G (sesame oil) and $\mathrm{H}$ (butterfat), thereby indicating that at the $75 \%$ level these fats enhance the intestinal synthesis of thiamine, whereas rats in groups $\mathrm{C}$ (hydrogenated groundnut oil) and $\mathrm{F}$ (coconut oil) showed a decrease in urinary and faecal excretions of thiamine. Those rats receiving only $15 \%$ hydrogenated groundnut oil (control) showed a further decrease in urinary and faecal excretion of thiamine; these animals died after 45 days from loss of appetite and thiamine deficiency, whereas rats receiving the low-fat diet supplemented with linoleic acid (group B) did not show any appreciable change in urinary and faecal excretion of thiamine, and died after 75 days. Animals receiving saturated fats (hydrogenated groundnut oil or 
coconut oil) at the higher level showed signs of essential fatty acid deficiency instead of thiamine deficiency, and only two of these rats survived to the end of the experiment.

The faecal bacteriological examinations at the end of each month showed that the numbers of coliform organisms increased in groups $\mathrm{D}, \mathrm{E}, \mathrm{G}$ and $\mathrm{H}$ (Table 3 ), but

Table 2. Effect of different food fats and linoleic acid on the urinary and faecal excretion of thiamine by rats after different periods on the diet

(Mean values and standard deviations for groups of eight rats)

\begin{tabular}{|c|c|c|c|c|c|c|}
\hline \multirow[b]{2}{*}{ Group and diet } & \multicolumn{6}{|c|}{ Urinary excretion* $(\mathrm{mg} / \mathrm{rat} 24 \mathrm{~h})$ on } \\
\hline & $\begin{array}{l}\text { I5th } \\
\text { day }\end{array}$ & $\begin{array}{l}\text { 3oth } \\
\text { day }\end{array}$ & $\begin{array}{l}45^{\text {th }} \\
\text { day }\end{array}$ & $\begin{array}{l}\text { 6oth } \\
\text { day }\end{array}$ & $\begin{array}{l}75^{\text {th }} \\
\text { day }\end{array}$ & $\begin{array}{l}\text { 9oth } \\
\text { day }\end{array}$ \\
\hline A (low-fat) & $\begin{array}{r}0.88 \\
\pm 0.07\end{array}$ & $\begin{array}{r}0.82 \\
\pm 0.06\end{array}$ & $\begin{array}{r}0.48 \\
\pm 0.02\end{array}$ & $-\dagger$ & - & - \\
\hline B (low-fat + linoleic acid) & $\begin{array}{r}1 \cdot 2 I \\
\pm 0.08\end{array}$ & $\begin{array}{r}1 \cdot 39 \\
\pm 0 \cdot 11\end{array}$ & $\begin{array}{r}1.02 \\
\pm 0.08\end{array}$ & $\begin{array}{r}1 \cdot 38 \\
\pm 0 \cdot 08\end{array}$ & $\begin{array}{r}\mathbf{r} \cdot 38 \\
\pm 0.11\end{array}$ & $-\dagger$ \\
\hline $\begin{array}{l}\text { C ( } 75 \% \text { hydrogenated groundnut } \\
\text { oil) }\end{array}$ & $\begin{array}{r}1.22 \\
\pm 0.07\end{array}$ & $\begin{array}{r}1 \cdot 35 \\
\pm 0.06\end{array}$ & $\begin{array}{r}r \cdot 84 \\
\pm 0.08\end{array}$ & $\begin{array}{r}2 \cdot 33 \\
\pm 0 \cdot 18\end{array}$ & $2.53 t$ & $2 \cdot 581$ \\
\hline $\begin{array}{l}\text { D (70\% hydrogenated groundnut } \\
\text { oil }+5 \% \text { linoleic acid) }\end{array}$ & $\begin{array}{r}2.21 \\
\pm 0.08\end{array}$ & $\begin{array}{r}2 \cdot 3^{8} \\
\pm 0 \cdot 10\end{array}$ & $\begin{array}{r}2.52 \\
\pm 0.08\end{array}$ & $\begin{array}{r}3.12 \\
\pm 0.21\end{array}$ & $\begin{array}{r}3 \cdot 18 \\
\pm 0 \cdot 12\end{array}$ & $\begin{array}{r}3 \cdot 10 \\
\pm 0 \cdot 16\end{array}$ \\
\hline E (75\% groundnut oil) & $\begin{array}{r}2 \cdot 38 \\
\pm 0 \cdot 12\end{array}$ & $\begin{array}{r}2.68 \\
\pm 0.18\end{array}$ & $\begin{array}{r}275 \\
\pm 0.09\end{array}$ & $\begin{array}{r}2 \cdot 78 \\
\pm 0 \cdot 11\end{array}$ & $\begin{array}{r}3.08 \\
\pm 0.13\end{array}$ & $\begin{array}{r}3 \cdot 08 \\
\pm 0.12\end{array}$ \\
\hline F ( $75 \%$ coconut oil) & $\begin{array}{r}\mathbf{I} \cdot 13 \\
\pm 0 \cdot 08\end{array}$ & $\begin{array}{r}1 \cdot 27 \\
\pm 0 \cdot 06\end{array}$ & $\begin{array}{r}r \cdot 83 \\
\pm 0.09\end{array}$ & $\begin{array}{r}2 \cdot 15 \\
\pm 0.12\end{array}$ & $2 \cdot 081$ & I $\cdot 98$ \\
\hline G $(75 \%$ sesame oil $)$ & $\begin{array}{r}2 \cdot 32 \\
\pm 0 \cdot 12\end{array}$ & $\begin{array}{r}2 \cdot 58 \\
\pm 0.08\end{array}$ & $\begin{array}{r}3.25 \\
\pm 0.15\end{array}$ & $\begin{array}{r}3 \cdot 38 \\
\pm 0 \cdot 11\end{array}$ & $\begin{array}{r}3.48 \\
\pm 0.17\end{array}$ & $\begin{array}{r}3.50 \\
\pm 0.20\end{array}$ \\
\hline \multirow[t]{3}{*}{$\mathrm{H}(75 \%$ butter $)$} & $\begin{array}{r}2 \cdot 58 \\
\pm 0.18\end{array}$ & $\begin{array}{r}2 \cdot 63 \\
\pm 0.18\end{array}$ & $\begin{array}{r}3.28 \\
\pm 0.21\end{array}$ & $\begin{aligned} & 4.15 \\
& \pm 0.11\end{aligned}$ & $\begin{array}{r}4.32 \\
\pm 0 \cdot 16\end{array}$ & $\begin{array}{r}4.28 \\
\pm 0.21\end{array}$ \\
\hline & \multicolumn{6}{|c|}{ Faecal excretion* (mg/rat $24 \mathrm{~h}$ ) on } \\
\hline & $\begin{array}{l}\text { I5th } \\
\text { day }\end{array}$ & $\begin{array}{l}\text { 3oth } \\
\text { day }\end{array}$ & $\begin{array}{l}\text { 45th } \\
\text { day }\end{array}$ & $\begin{array}{l}\text { 6oth } \\
\text { day }\end{array}$ & $\begin{array}{l}75^{\text {th }} \\
\text { day }\end{array}$ & $\begin{array}{l}\text { 9oth } \\
\text { day }\end{array}$ \\
\hline A (low-fat) & $\begin{array}{r}1 \cdot 08 \\
\pm 0.08\end{array}$ & $\begin{array}{r}1 \cdot 22 \\
\pm 0 \cdot 11\end{array}$ & $\begin{array}{r}1 \cdot 03 \\
\pm 0 \cdot 03\end{array}$ & - & - & - \\
\hline B (low-fat + linoleic acid) & $\begin{array}{r}2 \cdot 12 \\
\pm 0.03\end{array}$ & $\begin{array}{r}2 \cdot 30 \\
\pm 0.07\end{array}$ & $\begin{array}{r}2.33 \\
\pm 0.06\end{array}$ & $\begin{array}{r}2.32 \\
\pm 0.09\end{array}$ & $\begin{array}{r}2 \cdot 32 \\
\pm 0 \cdot 10\end{array}$ & - \\
\hline $\begin{array}{l}\text { C (75\% hydrogenated groundnut } \\
\text { oil) }\end{array}$ & $\begin{array}{r}r \cdot 88 \\
\pm 0.12\end{array}$ & $\begin{array}{r}1 \cdot 97 \\
\pm 0.09\end{array}$ & $\begin{array}{r}2 \cdot 02 \\
\pm 0.12\end{array}$ & $\begin{array}{r}3.42 \\
\pm 0.18\end{array}$ & $2 \cdot 8 \mathrm{I}$ & 2.80 \\
\hline $\begin{array}{l}\text { D ( } 70 \% \text { hydrogenated groundnut } \\
\text { oil }+5 \% \text { linoleic acid) }\end{array}$ & $\begin{array}{r}2.39 \\
\pm 0.09\end{array}$ & $\begin{array}{r}2 \cdot 82 \\
\pm 0.08\end{array}$ & $\begin{array}{r}3.48 \\
\pm 0.11\end{array}$ & $\begin{array}{r}3.53 \\
\pm 0.09\end{array}$ & $\begin{array}{r}3 \cdot 81 \\
\pm 0 \cdot 12\end{array}$ & $\begin{array}{r}4.07 \\
\pm 0.13\end{array}$ \\
\hline E (75\% groundnut oil) & $\begin{array}{r}2 \cdot 98 \\
\pm 0 \cdot 18\end{array}$ & $\begin{array}{r}3 \cdot 18 \\
\pm 0 \cdot 12\end{array}$ & $\begin{array}{r}3.32 \\
\pm 0.09\end{array}$ & $\begin{aligned} & 3.3^{8} \\
\pm & 0.11\end{aligned}$ & $\begin{array}{r}3 \cdot 68 \\
\pm 0 \cdot 18\end{array}$ & $\begin{array}{r}3.83 \\
\pm 0.12\end{array}$ \\
\hline F (75\% coconut oil) & $\begin{array}{r}I \cdot 93 \\
\pm 0.03\end{array}$ & $\begin{array}{r}2.28 \\
\pm 0.09\end{array}$ & $\begin{array}{r}245 \\
\pm 0.18\end{array}$ & $\begin{array}{r}2.38 \\
\pm 0.16\end{array}$ & $2 \cdot 23$ & $2 \cdot 03$ \\
\hline G (75\% sesame oil) & $\begin{array}{r}2.80 \\
\pm 0.18\end{array}$ & $\begin{array}{r}3.01 \\
\pm 0.15\end{array}$ & $\begin{array}{r}3.68 \\
\pm 0.2 I\end{array}$ & $\begin{array}{r}3.62 \\
\pm 0.12\end{array}$ & $\begin{array}{r}4.08 \\
\pm 0.16\end{array}$ & $\begin{array}{r}4.18 \\
\pm 0.18\end{array}$ \\
\hline H $(75 \%$ butter $)$ & $\begin{array}{r}3.18 \\
\pm 0.08\end{array}$ & $\begin{array}{r}3.28 \\
\pm 0.10\end{array}$ & $\begin{array}{r}3.82 \\
\pm 0.1 \mathrm{I}\end{array}$ & $\begin{array}{r}3.82 \\
\pm 0.12\end{array}$ & $\begin{array}{r}4.22 \\
\pm 0.11\end{array}$ & $\begin{array}{r}4.27 \\
\pm 0.18\end{array}$ \\
\hline
\end{tabular}

* Initial urinary and faecal excretions of thiamine were 0.7 and $\mathrm{I} \cdot 8 \mu \mathrm{g} / \mathrm{rat} 24 \mathrm{~h}$ respectively.

$\uparrow$ All animals died.

$\ddagger$ Value for two animals only. 
were reduced in groups $C$ and $F$. The rats in groups $D, E, G$ and $H$ stored more thiamine in tissues and caecums than those in the remaining groups (Table 4), and showed a steady increase in weight.

Table 3. Mean values ( $\times 10^{-4} / g$ wet faeces) for faecal coliform and lactobacillus counts of groups of four rats after different periods on the diet

\begin{tabular}{|c|c|c|c|c|c|c|}
\hline \multirow[b]{2}{*}{ Group and diet } & \multicolumn{2}{|c|}{30 th day } & \multicolumn{2}{|c|}{$60 t h$ day } & \multicolumn{2}{|c|}{ 9oth day } \\
\hline & Coliform & $\begin{array}{l}\text { Lacto- } \\
\text { bacilli }\end{array}$ & Coliform & $\begin{array}{l}\text { Lacto- } \\
\text { bacilli }\end{array}$ & Coliform & $\begin{array}{l}\text { Lacto- } \\
\text { bacilli }\end{array}$ \\
\hline & $2 \cdot 3$ & $3 \cdot 8$ & 一* & - & - & - \\
\hline+ linoleic acid) & 4.8 & $12 \cdot 2$ & $3 \cdot 2$ & $12 \cdot 8$ & $\ldots$ & - \\
\hline ydrogenated groundnut & $5 \cdot 2$ & II 8 & 6.8 & $13 \cdot 2$ & $3.9 \dagger$ & I2.9† \\
\hline $\begin{array}{l}\text { ydrogenated groundnut } \\
\text { linoleic acid) }\end{array}$ & $8 \cdot 8$ & $12 \cdot 3$ & $13 \cdot 2$ & $13 \cdot 2$ & I $8 \cdot 0$ & $13 \cdot 0$ \\
\hline undnut oil) & $7 \cdot 3$ & $12 \cdot 2$ & I $I \cdot 3$ & $13 \cdot 9$ & $12 \cdot 8$ & $14 \cdot 2$ \\
\hline conut oil) & $4 \cdot 8$ & $12 \cdot 2$ & $3 \cdot 6$ & $13 \cdot 8$ & $3 \cdot 2$ & $3 \cdot 2$ \\
\hline ame oil) & $7 \cdot 8$ & I I.9 & $12 \cdot 2$ & $14 \cdot 3$ & $12 \cdot 6$ & $3 \cdot 0$ \\
\hline tter) & 10.6 & $18 \cdot 3$ & 13.2 & $20 \cdot 2$ & $14 \cdot 3$ & 20.3 \\
\hline
\end{tabular}

* Animals died.

$\uparrow$ Values for two animals only.

Table 4. Effect of different food fats on tissue thiamine content and body-weight of rats

(Mean values with their standard deviations for groups of eight rats)

A (low-fat)

B (low-fat + linoleic acid)

C $(75 \%$ hydrogenated groundnut oil)

D (70\% hydrogenated groundnut oil $+5 \%$ linoleic acid)

E (75\% groundnut oil)

G $(75 \%$

$\mathrm{H}$ (75\% butter)

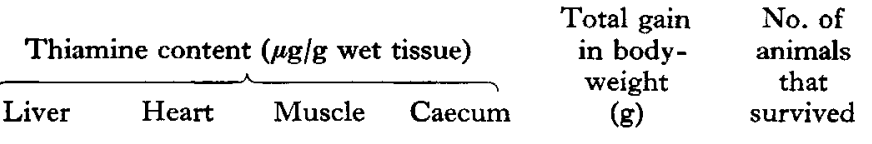

A (low-fat)

B (low-fat + linoleic acid)

C (75\% hydrogenated

groundnut oil)

D (70\% hydrogenated groundnut oil $+5 \%$ linoleic acid)

E ( $75 \%$ groundnut oil)

F ( $75 \%$ coconut oil)

G (75\% sesame oil)

$\begin{array}{ll}- & - \\ 0.51 & 0.48\end{array}$

-

(g)

urvived

H ( $75 \%$ butter)

I.I $\quad 0.68$

$\begin{array}{rr}I \cdot 18 & 0.68 \\ \pm 0.03 & \pm 0.08\end{array}$

0.82

0.52

$\pm 0.06$

$\pm 0.06$

0.58

0.58

1.00

$\pm 0.03$

$\pm 0.04$

0.72

$\pm 0.10$

$\pm 0.06$

$\begin{array}{rr}- & - \\ 0.18 & 1.23 \\ 0.28 & 2.12 \\ \pm 0.05 & \pm 0.09 \\ & \\ 0.23 & 1.88 \\ \pm 0.08 & \pm 0.07 \\ 0.14 & 0.98 \\ 0.21 & 1.96 \\ \pm 0.02 & \pm 0.09 \\ 0.23 & 1.89 \\ \pm 0.07 & \pm 0.03\end{array}$

-

$\circ$

0

289

8

\section{DISCUSSION}

The results of this study show that the high-fat diets helped the synthesis of thiamine in the intestinal tract of the rat. High-fat diets enhanced thiamine synthesis, and it was found that the extent of this synthesis was influenced by the nature of the fat present in the diet. Natural fats that contain much essential fatty acid were more effective than the saturated ones, such as hydrogenated groundnut oil or coconut oil. Hydrogenated groundnut oil supplemented with linoleic acid promoted more synthesis of thiamine than did the oil alone. 
Evans \& Lepkovsky (I935) reported that there was less tissue storage of thiamine in animals on low-fat diets and more in those on high-fat diets. They further reported continued increase in weight and absence of typical deficiency signs in rats on the thiamine-free diet containing $50 \%$ lard. Evans et al. (I934b) observed that the chemical nature of the fat influenced its sparing action and also reported that animals given coconut oil in their diet could survive for more than 120 days, whereas those given sesame oil survived for only 50 days. However, our results show that sesame oil was far more effective than coconut oil in promoting the growth of rats, and animals given sesame oil could survive for more than 90 days. Butterfat, which is relatively saturated, gave rise to enhanced thiamine synthesis; this effect of butter may be attributable to the presence of essential fatty acids (Hilditch \& Sleightholme, I93I).

In recent years a more detailed study of the thiamine-sparing action has been made by Scott \& Griffith (1957), who have shown that, since no metabolic relationship exists between thiamine and fat, the metabolic explanation of thiamine-sparing action is not correct; they suggested that fat in the diet might alter the intestinal flora. It seems possible from our results that the numbers of coliform organisms are increased by butterfat, sesame oil and hydrogenated groundnut oil supplemented with linoleic acid and in turn enhance thiamine synthesis. We have previously reported that intestinal thiamine synthesis depends upon the nature of the carbohydrate in the food and that the flora is also altered thereby (Nath \& Meghal, 1961). Thiamine thus synthesized is excreted in the faeces and made available after coprophagy (Meghal \& Nath, 1963).

\section{SUMMARY}

I. Sixty-four male rats were depleted of thiamine. They were then divided into eight groups and given for 3 months, with the thiamine-free diet, $15 \%$ hydrogenated groundnut oil, or $75 \%$ of either groundnut oil, hydrogenated groundnut oil, coconut oil, sesame oil or butterfat, or $13 \%$ hydrogenated groundnut oil $+2 \%$ linoleic acid, or $70 \%$ hydrogenated groundnut oil $+5 \%$ linoleic acid. The effects on urinary and faecal excretion of thiamine and on faecal flora were studied.

2. The animals on the low-fat diet without linoleic acid soon died of thiamine deficiency.

3. The high-fat diet increased urinary and faecal excretion of thiamine, sesame oil and butter being the most effective in this respect and hydrogenated groundnut oil and coconut oil the least.

4. Replacing part of the hydrogenated groundnut oil with linoleic acid increased urinary and faecal excretion of thiamine, the faecal coliform count and tissue storage of thiamine.

5. It is suggested that a high-fat diet increases thiamine synthesis in the intestine of thiamine-deficient rats, but that the size of the increase depends on the degree of saturation of the fat and the presence in it of essential fatty acids. 


\section{REFERENCES}

Association of Vitamin Chemists (195I). Methods of Vitamin Assay, 2nd ed. New York: Interscience Publishers Inc.

Balkrishnan, S. \& Rajagopalan, R. (1952). Indian f. Physiol. 6, I43.

Balkrishnan, S. \& Rajagopalan, R. (1954). Sci. Eळ Cult. 19, 359.

Banerjee, G. G. (1940). Biochem. F. 34, ${ }_{329}$.

Evans, H. M. \& Lepkovsky, S. (1928). Science, 68, 298.

Evans, H. M. \& Lepkovsky, S. (1929). F. biol. Chem. 83, 269.

Evans, H. M. \& Lepkovsky, S. (1935). F. biol. Chem. 108, 439.

Evans, H. M., Lepkovsky, S. \& Murphy, E. A. (1934a). F. biol. Chem. I07, 429.

Evans, H. M., Lepkovsky, S. \& Murphy, E. A. (1934b). F. biol. Chem. 107, 439.

Hennessey, D. J. \& Cerecedo, L. R. (1939). J. Amer. chem. Soc. 6r, I79.

Hilditch, T. P. \& Sleightholme, J. J. (193 I). Biochem. f. 35, 507.

Jones, J. H. \& Foster, C. (1942). $\mathscr{~}$. Nutr. 24, 245.

Kemmerer, A. R. \& Steenbock, H. (1933). F. biol. Chem. 103, 353.

Kratzing, C. C. \& Slater, E. C. (1950). Biochem. Y. 47, 24.

Mawson, E. H. \& Thompson, S. Y. (1948). Biochem. F. 43, 2.

Meghal, S. K. \& Nath, M. C. (1963). Nature, Lond., 198, 89.

Nath, M. C. \& Meghal, S. K. (196r). Biochem. F. 81, 220.

Scott, E. M. \& Griffith, I. V. (1957). F. Nutr. 6r, 421.

Whipple, D. V. \& Church, C. F. (1935). F. biol. Chem. 109, xcviii. 